\title{
NUTRITIONAL QUALITY AND ANTIOXIDANT ACTIVITY OF MARAMA- SORGHUM COMPOSITE FLOURS AND PORRIDGES
}

\author{
Eugénie Kayitesi ${ }^{1,2}$, Henriette L. de Kock ${ }^{1}$, Amanda Minnaar ${ }^{1}$ and Kwaku Gyebi \\ $\operatorname{Duodu}^{1^{*}}$, \\ 1. Department of Food Science, University of Pretoria, Pretoria 0002, South Africa \\ 2. Department of Food Science, Kigali Institute of Science and Technology, Kigali 3900, Rwanda
}

\begin{abstract}
Marama bean, an underutilised legume in southern Africa, is a good source of protein, fat and phenolic compounds, the latter known to have potential health benefits. Marama flours, sorghum meal, marama-sorghum composite flours and porridges were analysed for proximate composition, amino acid composition, energy value, fatty acid composition, total phenolic content and antioxidant activity. Compositing sorghum meal (70\%) with marama flours (30\%) significantly increased protein and fat contents in flours and porridges. Energy values of marama-sorghum composite porridges were $11-24 \%$ higher than sorghum porridge. Lysine content was 3 to 4 times higher in marama-sorghum porridges than in sorghum porridge. There was an increase in oleic acid as sorghum meal was composited with marama flour. There was a positive correlation between the total phenolic content and antioxidant activity in all samples. Use of marama flour in sorghum composite flours and porridges improved nutritional quality and antioxidant activity.
\end{abstract}

Key words: Marama, sorghum, composites, flours, porridges, nutritional quality, antioxidant activity

\footnotetext{
"Corresponding author: Gyebi.Duodu@up.ac.za
} 


\section{INTRODUCTION}

Marama bean Tylosema esculentum (Burch) A. Schreib is a wild underutilised legume in southern Africa and is used as a food source by the rural communities of the Kalahari desert (Jackson, Duodu, Holse, Lima de faria, Jordaan, Chingwaru, Hansen, Cencic, Kandawa-schultz, Mpotokwane, Chimwamurombe, de Kock and Minnaar, 2010). Marama bean is a good source of protein (29-38\%) and fat (32-42\%) (Holse, Husted and Hansen, 2010). It can potentially be used to enhance the nutritional quality of cereal products such as sorghum.

Sorghum bicolor (L.) Moench is a major staple food in many African countries where agricultural and environmental conditions are unfavourable for the production of other crops (Rooney and Serna-Saldivar, 1990). However sorghum, like other cereals, has low protein content, and is deficient in the essential amino acid lysine. Compositing sorghum with marama flour may contribute to better amino acid balance, increased protein content and energy value and could help alleviate protein energy malnutrition in developing countries.

Other marama bean constituents such as phenolic compounds are believed to have antioxidant properties (Nandutu, Clifford and Howell, 2007). Reports indicate that diets rich in phenolic compounds may play a role in the prevention of various diseases associated with oxidative stress such as cancer, cardiovascular and neurodegenerative diseases (Anderson and Wolf, 1995). Marama bean cotyledon is reported to have 2.8 mg CE/100g total phenolic content (Jackson et al., 2010). Phenolic content and antioxidant activity of sorghum-marama composite flours and their porridges have not been investigated.

Previously, Kayitesi, Duodu, Minnaar and de Kock (2010) found that combining sorghum meal with full fat marama bean flour has the potential to improve the 
sensory quality of sorghum porridge. These researchers reported in detail on the effects of dry heating or roasting of marama beans, defatting and combining the resultant flours with sorghum meal on the sensory quality of porridges made from the flours in terms of descriptive sensory evaluation, consumer sensory evaluation and objective textural and colour measurements. However, the effects of these treatments on the nutritional and phytochemical quality of sorghum-marama composite flours and porridges have not yet been reported.

Production of marama flours involves processes such as dry heating the beans (roasting), oil extraction and milling (Maruatona, Duodu and Minnaar, 2010). These processes can affect the nutritional quality of the resultant flour. This will in turn affect the nutritional value of composite flours and porridges if marama flour is used in composite foods. Such processing can also affect phenolic content and antioxidant activity. This study aims at evaluating the potential of full fat and partially defatted marama bean flours in improving the nutritional quality of sorghum porridge, and also the effect on phenolic content and antioxidant activity.

\section{MATERIALS AND METHODS}

\subsection{Preparation of marama flours}

The marama bean flours were prepared as previously described by Maruatona et al. (2010) with modifications by Kayitesi et al. (2010). Four marama flour samples were prepared and were denoted full fat flour from heated marama beans $(\mathrm{FH})$, full fat flour from unheated marama beans $(\mathrm{FUH})$, partially defatted flour from heated marama beans (DH) and partially defatted flour from unheated marama beans (DUH). The heating process was conducted by dry heating the marama beans at $150^{\circ} \mathrm{C}$ for $20 \mathrm{~min}$ (Maruatona et al. 2010) using a forced convection continuous tumble roaster 
(Roastech, Bloemfontein, South Africa). A DF sample cracker (WMC Metal Sheet Works, Tzaneen, South Africa) was used to dehull marama beans (dry heated and unheated) prior to milling. Marama beans were coarse ground and oil was extracted using hexane (1 part ground flour to 3 parts hexane) for $2 \mathrm{~h}$. The hexane was decanted off, and the procedure was repeated 3 times. After oil extraction, the flour was left to dry in a fume cupboard for $24 \mathrm{~h}$ and milled again to pass through a $1000 \mu \mathrm{m}$ mesh. Marama flours were vacuum packed and stored at $4{ }^{\circ} \mathrm{C}$.

\subsection{Preparation of marama-sorghum composite flours and porridges}

Composite flours and porridges were prepared as described previously by Kayitesi et al. (2010).

\subsection{Proximate composition}

Moisture was determined using the AACC Method 44 - 15A (American Association of Cereal Chemists - AACC, 1999). Crude protein was determined using the thermal combustion (Dumas) method with the Leco FP - 528 Protein/Nitrogen Analyzer (Leco Corporation, USA). The nitrogen content was converted to \% protein by using a protein conversion factor of 6.25. Crude fat was determined by extraction of $3 \mathrm{~g}$ of the sample with $40 \mathrm{~mL}$ petroleum ether (boiling point $40-60^{\circ} \mathrm{C}$ ) for $4 \mathrm{~h}$ according to AACC method 30-25 (1983) using a Soxhlet test apparatus. AACC method $08-01$ (1999) was used to determine the ash content. Total carbohydrate was calculated by difference. 


\subsection{Amino acid composition}

Amino acid composition was determined using the PICO-TAG method (Bidlingmeyer, Cohen, and Tarvin, 1984). The results were expressed as g/100 g sample on dry basis.

\subsection{Fatty acid composition}

The fatty acid composition was determined using a modification of the methods described by Alonso et al. (2004) and Genet et al. (2004). The results were expressed as mol \% fatty acid (as is basis).

\subsection{Gross energy determination}

Gross energy was determined using the water bomb calorimeter (MC-1000 modular calorimeter, Energy Instrumentation, 135 Knoppieslaagte, Centurion, South Africa). The process essentially involves measuring the energy evolved on total combustion of the sample in a stream of oxygen. The results were expressed in $\mathrm{kJ} / 100 \mathrm{~g}$ of porridge (dry basis).

\subsection{Total phenolic content and antioxidant activity determination}

\subsubsection{Sample preparation}

Acidified methanol $(1 \% \mathrm{HCl}$ in methanol) was used as the extracting solvent for determination of total phenolic content and antioxidant activity of the flours and porridges. Duplicate samples were extracted with $30 \mathrm{~mL}$ solvent in three phases as follows: $10 \mathrm{~mL}$ solvent was added to $0.3 \mathrm{~g}$ of the sample in a conical flask and completely covered with aluminium foil and stirred for $2 \mathrm{~h}$, transferred to $40 \mathrm{~mL}$ plastic centrifuge tubes, centrifuged at $3500 \mathrm{rpm}$ for $10 \mathrm{~min}\left(25^{\circ} \mathrm{C}\right)$ using a Rotanta 460 R centrifuge (Labotech T., Johannesburg, South Africa) and decanted, keeping 
the supernatant. The sample residue was rinsed again with $10 \mathrm{~mL}$ of the solvent, stirred for $20 \mathrm{~min}$, centrifuged again as above and decanted, keeping the supernatant. This step was repeated as in the second time and the supernatants were combined and stored in a glass bottle covered with aluminium foil and kept in a cold room until analysed.

\subsubsection{Determination of total phenolic content}

The total phenolic content of the flours and porridges extracts was determined using the Folin-Ciocalteu method (Singleton and Ross, 1965) as described by Waterman and Mole (1994). Briefly, the methanolic extract $(0.5 \mathrm{~mL})$ was reacted with $2.5 \mathrm{~mL}$ Folin-Ciocalteu's phenol reagent in the presence of $7.5 \mathrm{~mL} 20 \%(\mathrm{~m} / \mathrm{v})$ sodium carbonate $\left(\mathrm{Na}_{2} \mathrm{CO}_{3}\right)$ solution for $2 \mathrm{~h}$. The absorbance was measured at $760 \mathrm{~nm}$ using a Lambda EZ150 spectrophotometer (Perkin Elmer, USA). Catechin was used as a standard and the results were expressed as catechin equivalents (CE, mg catechin equivalents/100 mg sample) on dry matter basis.

\subsubsection{Determination of antioxidant activity}

The free radical scavenging activity of the methanolic extracts of the flours and porridges was determined using the Trolox Equivalent antioxidant capacity (TEAC) assay $\left(\mathrm{ABTS}^{+\bullet}\right.$ free radical scavenging) as described by Awika, Rooney, Wu, Prior and Cisneros-Zevallos (2003) with slight modifications. Aliquots $(0.1 \mathrm{~mL})$ of methanolic extracts or Trolox standard solution (prepared in acidified methanol) were reacted with $2.9 \mathrm{~mL} \mathrm{ABTS}^{+}$radical cation working solution for $30 \mathrm{~min}$. The absorbance of the standards and samples was measured at $734 \mathrm{~nm}$ using a Lambda EZ150 spectrophotometer (Perkin Elmer, USA). The results were expressed as $\mu \mathrm{M}$ Trolox equivalent/100 mg sample, on dry matter basis. 


\section{Statistical analyses}

The analyses were performed in triplicate and experiments repeated twice. Data obtained was analysed by one-way ANOVA. Mean differences were evaluated at the 95\% significance level $(\mathrm{p} \leq 0.05)$ using the least significant difference test. The statistical analyses were performed using Statistica Version 8.0 (Statsoft, Tulsa, USA).

\section{RESULTS AND DISCUSION}

\subsection{Proximate composition}

Partially defatted and full fat marama bean flours were higher in protein, fat and ash contents compared to sorghum meal (Table 1). Partially defatted marama flours (DH, DUH) were higher in protein and lower in fat content than full fat marama flours (FH, FUH). Oil extraction reduced fat in the partially defatted flours, and concentrated other constituents, hence the higher protein content in defatted flours. Full fat marama flours had similar protein and fat contents to those reported by Amarteifio and Moholo (1998), Holse et al. (2010), Jackson et al. (2010) and Maruatona et al. (2010). Partially defatted flour from dry heated marama beans (DH) had higher protein content and lower fat content than partially defatted flour from unheated marama beans (DUH).

A similar result was reported by Maruatona et al. (2010). This was explained by the disruption of lipid bodies of the marama beans upon heating allowing the oil to be more readily expelled. The relatively lower fat content of DH contributes to concentrating its protein content compared to DUH. Though the fat content of FH (39\%) and FUH (38\%) was statistically different, this may not be of practical significance since the two values are essentially close to each other. 
Marama-sorghum composite flours (FUMSF, FHMSF, DUMSF and DHMSF) had up to 2.4 times the protein content and up to 5 times the fat content of sorghum meal. Increase in protein $(24.5 \%)$ and fat $(12.9 \%)$ contents in maize composite flours when composited with African oil bean flour compared to maize flour has been reported by Enujiugha (2006). Compositing sorghum meal with marama flours also increased protein and fat contents in marama-sorghum composite porridges. Protein increases in marama-sorghum composite porridges ranged from $61 \%$ in porridges composited with full fat flours (FHMSP and FUMSP) to $96 \%$ in porridges composited with partially defatted flour (DHMSP and DUMSP) compared with sorghum porridge. Fat increase ranged from $92.8 \%$ in DHMSP and DUMSP to $807 \%$ in FHMSP and FUMSP compared with sorghum porridge. This is because marama flour has high protein and fat contents and thus contributes to increased levels of fat and protein in composite porridges. Increase in protein in cereal-legume based complementary foods has been reported by Solomon (2005).

Protein is an essential macronutrient for growth and maintenance of body tissues (WHO/FAO, 1985). Increase in fat content of the porridges is also important because fat increases the energy density of the porridges, provides essential fatty acids and facilitates the absorption of fat-soluble vitamins. In addition, fats slow gastric emptying and intestinal motility thus affecting satiety (Mosha and Vincent, 2005). Thus, use of marama flour in sorghum composite flours enhances the nutritional quality of the porridges.

Compositing marama bean flour with sorghum meal significantly reduced the carbohydrate content. Marama bean stores energy as fat and has low carbohydrate content. On the other hand sorghum stores energy as carbohydrate. Therefore 
compositing sorghum meal with marama had a diluting effect on the carbohydrate content.

Marama-sorghum composite flours made with partially defatted marama flour had significantly higher protein and lower fat contents than composite flours made with full fat marama flours. This is possibly because of the original protein and fat contents of partially defatted and full fat marama flours prior to compositing with sorghum meal. Heating marama beans prior to defatting and compositing the flour with sorghum meal did not significantly affect the protein and fat contents in composite porridges.

\subsection{Energy value}

The energy values of marama-sorghum porridges and sorghum porridge are summarised in Table 2. The energy values of the porridges were in accordance with the recommendations of WHO/FAO, (1985) which specify $1.0 \mathrm{Kcal} / \mathrm{g}$ or $4.19 \mathrm{~kJ} / \mathrm{g}$ for children 2 to 5 years. Energy values of marama-sorghum composite porridges were $11-24 \%$ higher compared to sorghum porridge.

Marama-sorghum composite porridges with full fat flours were significantly higher in energy values than porridges composited with partially defatted flours. From the perspective of contribution to energy value, it may therefore be advantageous to composite sorghum meal with full fat marama flour. Kayitesi et al. (2010) reported that marama-sorghum composite porridges with full fat flours were more acceptable to consumers than porridges composited with partially defatted flours. Formulations of composite food mixtures of cereal, legumes and oil seeds has been proposed as a practical and sustainable approach for improving macronutrient and energy status of 
weaning foods in developing countries (Mosha and Vicent, 2005). The results obtained in this study support this proposal.

\subsection{Amino acid composition}

Table 3 shows the amino acid composition of the marama bean flours compared with sorghum meal. Essential and non-essential amino acid contents of the flours were determined except tryptophan. Marama bean flours were higher than sorghum meal in all amino acids except for cysteine. Glutamic acid and tyrosine were the most abundant amino acids in marama bean flours.

Lysine is a major limiting amino acid in sorghum. Lysine content in DUH (2.8\%) and DH (2.7\%) was significantly higher than SOGF (0.2\%). The lysine content in marama bean flours was similar to that reported by Maruatona et al. (2010) in partially defatted flour from unheated marama bean (3.1\%) and partially defatted flour from heated marama bean (2.8\%). Compositing sorghum meal with marama flour would be expected to increase lysine content hence its nutritional quality. Dry heating marama beans prior to flour processing slightly reduced lysine but this may be considered practically insignificant. The reduction of lysine in marama bean flour as a result of dry heating the beans has also been reported by Mmonatau (2005) and Maruatona et al. (2010). This may be attributed to Maillard reactions of the $\varepsilon-\mathrm{NH}_{2}$ group of lysine with reducing sugars.

Marama-sorghum composite porridges generally had higher amino acid content than sorghum porridge (Table 4). Improvement in amino acid content of sorghum gruels when composited with peanut and SUA-90 bean flours was reported by Mosha and Vincent (2005). 
Lysine content was 3 to 4 times higher in marama-sorghum porridges than in sorghum porridge. The main role of lysine is to participate in protein synthesis, thus it is important for growth and maintenance of the body. Amino acid contents in maramasorghum composite porridges from partially defatted flour were significantly higher than composite porridges prepared from full fat flours. This is possibly because oil extraction concentrated protein and amino acid content of marama-sorghum porridges composited with defatted flour.

\subsection{Fatty acid composition}

The fatty acid composition of marama-sorghum composite porridges and sorghum porridge are shown in (Table 5). Generally unsaturated fatty acids were the most abundant in both marama-sorghum composite porridges and sorghum porridge. There was an increase of up to 18 to $43 \%$ in oleic acid when sorghum meal was composited with marama flour. According to Bower et al. (1988) and Mitei, Ngila, Yeboah, Wessjohann and Schmidt (2008), oleic acid is the most abundant fatty acid in marama bean. This explains the higher oleic acid content in marama-sorghum composite porridges than in sorghum porridge. Food sources with high oleic acid levels such as olive oil have been reported to have cardio-protective effects (Hu, Manson and Willet, 2001). Dry heating marama beans prior to flour processing did not have a significant effect on the fatty acid contents of marama-sorghum composite porridges.

Total saturated fatty acids ranged from $24.9 \%$ to $26.4 \%$ in marama-sorghum composite porridges and $28 \%$ in sorghum porridges. Palmitic acid and stearic acid were the most abundant saturated fatty acids both in sorghum and marama-sorghum composite porridges. Myristic acid was not detected in the composite porridges. The ratio of unsaturated : saturated fatty acid is used to express the health value of a fat. 
The balance is important with respect to coronary heart disease (Anderson, 2004). Saturated fatty acids elevate serum cholesterol and LDL, while unsaturated fatty acids lower the same (FAO/WHO, 1998). Additionally, essential fatty acids are vital for normal fetal development and infant growth, since infants generally utilise the essential fatty acids to synthesise other long chain PUFA used extensively for the central nervous system membrane and photoreceptor cell development during the first year of life (Fernandez, et al., 2002).

\subsection{Total phenolic content and antioxidant activity}

Total phenolic content (TPC) and antioxidant (free radical scavenging) activity of the flours and the porridges are summarised in Table 6. Marama flours were significantly higher in total phenolic content by 4 to 8 times than sorghum meal. Antioxidant activity was also significantly higher in marama flours than in sorghum meal (4.7 to 5 times). Marama flour has high tyrosine content which reacts with the Folin-Ciocalteu reagent thus increasing levels of measurable phenols and L-tyrosine also exhibits antioxidative properties (Meucci and Mele, 1997).

Total phenolic contents were significantly higher in partially defatted marama flours than in full fat flours. This could possibly be due to oil extraction in defatted flour that concentrated other constituents hence an increase in total phenolics. Total phenolic content of full fat marama flour from unheated beans $(3.0 \mathrm{mg} \mathrm{CE} / 100 \mathrm{mg})$ was similar to $2.8 \mathrm{mg} \mathrm{CE} / 100 \mathrm{mg}$ in marama cotyledon reported by Jackson et al. (2010). Dry heating marama beans prior to flour processing increased total phenolic content and antioxidant activity of the flours. Increase in total phenolic content and antioxidant activity following roasting peanuts has been reported by Talcott, Passeretti, Duncan and Gorbet (2005). Dewanto, Wu and Liu (2002) reported that thermal processing 
may release bound phenolics from cellular constituents. Additionally, heating induces production of Maillard reaction products, especially melanoidins, which have been reported to have antioxidant activity (Michalska, Amigo-benaventb, Zielinski, and Dolores Del Castillo, 2008).

Marama-sorghum composite flours and porridges had higher total phenolic content and antioxidant activity than sorghum meal and porridge (Table 6). Porridges and flours composited with partially defatted marama flours had significantly higher total phenolic content and antioxidant activity than porridges and flours composited with full fat flours.

There was a significant positive correlation $\left(\mathrm{R}^{2}=0.80, \mathrm{p}<0.05\right)$ between the total phenolic content and antioxidant activity of the flours and the porridges. This means high phenolic content led to high antioxidant activity. Free radicals and other reactive oxygen species contribute to the development of many diseases (Shahidi and Naczk, 2004). Phenolic compounds scavenge free radicals by donating hydrogen atoms to free radicals; hence may protect cell constituents against oxidative damage and limit the risk of various degenerative diseases associated with oxidative stress (Anderson et al., 1995).

\section{CONCLUSIONS}

Marama-sorghum composite porridges have improved nutritional quality compared to sorghum porridge in terms of protein content, essential amino acids, fatty acids and energy densities. Marama-sorghum composite porridges are important not only for their nutritional contribution but also for potential anti-oxidative benefits associated with their high levels of phenolic compounds. Use of full fat flours in compositing 
sorghum meal is recommended to achieve high nutrient content and protein complementarity, which in turn improves both protein and energy utilisation.

\section{ACKNOWLEDGEMENT}

This research was sponsored by the EU MARAMA II PROJECT.

\section{REFERENCES}

Alonso, L., Cuesta, E. P., \& Gilliland, S. E. (2004). Gas chromatographic method for analysis of conjugated linoleic acids isomers in broth media as application in probiotic studies. Journal of Chromatographic Science, 42, 167-170.

Amarteifio, J. O., \& Moholo, D. (1998). The chemical composition of four legumes consumed in Botswana. Journal of Food Composition and Analysis, 11, 329332.

American Association of Cereal Chemists (AACC) (1983). Approved Methods of the $A A C C\left(10^{\text {th }}\right.$ Ed.). St. Paul, MN: AACC.

American Association of Cereal Chemists (AACC) (1999). Approved Methods of the $A A C C\left(10^{\text {th }}\right.$ Ed.). St. Paul, MN: AACC.

Anderson, L. R., \& Wolf, J. W. (1995). Compositional changes in trypsin inhibitor, phytic acid, saponins and isoflavones related to soya bean processing. Journal of Nutrition, 581S-588S.

Anderson, D. M. (2004). Nutrition for low birth weight infants. In L. K. Mshan, \& S. Escott-Stump (Eds.), Krause's Food, Nutrition and Diet Therapy. (11 ${ }^{\text {th }}$ Ed). London: Saunders. 
Awika, J. M., Rooney, L. W., Wu, X., Prior, R. L., \& Zevallos, L.C. (2003). Screening methods to measure antioxidant activity of sorghum (Sorghum bicolor) and sorghum products. Journal of Agricultural and Food Chemistry, $51,6657-6662$.

Bidlindmeyer, B. A., Cohen, S. A., \& Tarvin, T. L. (1984). Rapid analysis of amino acids using pre-column derivatization. Journal of Chromatography, 336, 93104.

Bower, N., Hertlet., O. H, J., \& Storey, R. (1988). Nutritional evaluation of marama bean (Tylosema esculentum): Analysis of the seed. Economic Botany, 42, 533540.

Dewanto, V., Wu, X., \& Liu, T. H. (2002). Processed sweet corn has higher antioxidant activity. Journal of Agricultural and Food Chemistry, 50, 49594964.

Enujiugha, V. N., 2006. Supplementation of ogi, a maize-based infant weaning food, with African oil bean (Penthaclethra Macrophylla Benth). Journal of Food, Agriculture and Environment, 4, 34-38.

FAO/WHO. (1998). Preparation and use of food-based dietary guidelines. Report of Joint FAO/WHO Consultation (WHO Technical Report Series 880) Geneva.

Fernandez, R. A., Vanderjagt. J. D., Williams, M., Huang, Y. S., Chuang Lu-Te., Millson, M., Andrews, R., Pastuszyn. A., \& Glew. H. R., (2002). Fatty acid, amino acid and trace mineral analyses of five weaning foods from Jos, Nigeria. Plant Foods for Human Nutrition, 57, 257-274. 
Genet, T., Labschagne, M. T., \& Hugo. A. (2004). Capillary gas chromatography analysis of Ethiopian mustard to determine variability of fatty acid composition. Journal of the Science of Food and Agriculture, 84, 1663-1670.

Holse, M., Husted, S., \& Hansen, A. (2010). Chemical composition of marama bean (Tylosema esculentum) - A wild African bean with unexploited potential. Journal of Food Composition and Analysis, 23, 648-657.

Hu, F. B., Manson, J. E., \& Willet, W. C. (2001). Types of dietary fat and risk of coronary heart disease. Journal of the American College of Nutrition, 20, 5-19.

Jackson, J.C., Duodu, K.G., Holse, M., Lima de faria, M. D., Jordaan, D., Chingwaru, W., Hansen, A., Cencic,A., Kandawa-schultz, M., Mpotokwane, S. M., Chimwamurombe, P., De Kock, H. L., \& Minnaar, A. (2010). The Morama Bean (Tylosema esculentum): A Potential Crop for Southern Africa. Advances in Food and Nutrition Research, 61, 1043-4526.

Kayitesi, E., De Kock, H. L., Duodu, K. G., \& Minnaar, A. (2010). Sensory quality of marama/sorghum composite porridges. Journal of the Science of Food and Agriculture, 90, 1959-2152.

Maruatona, G. N., Duodu, K. G., \& Minnaar, A. (2010). Physicochemical, nutritional and functional properties of marama bean flour. Food Chemistry, 121, 400-405.

Meucci, E., \& Melle, M. C. (1997). Amino acid and plasma antioxidant activity. Amino acid, 12, 373-377.

Michalska, A., Amigo-benaventb, M., Zielinski, H., \& Dolores Del Castillo, M. (2008). Effect of bread making on formation of Maillard reaction products contributing to the overall antioxidant activity of rye bread. Journal of Cereal Science, 48, 123-132. 
Mitei, Y. C., Ngila, J. C., Yeboah, S. O., Wessjohann, L., \& Schmidt, J. (2008). NMR, GC-MS and ESI-FTICR-MS profiling of fatty acids and triacylglycerols in some Botswana seed oils. Journal of American Oil Chemists Society, 85, $1021-1032$.

Mmonatau, Y. (2005). Flour from the marama bean: composition and sensory properties in a Botswana perspective. MSc Thesis, Stellenbosch University, Cape Town, South Africa.

Mosha, T. C. E., \& Vincent, M. M. (2005). Nutritional quality, storage stability and acceptability of home-processed ready-to eat composite foods for rehabilitating undernourished preschool children in low income countries. Journal of Food Processing and Preservation, 29, 331-356.

Nandutu, A. M., Clifford, M., \& Howell, N. K. (2007). Analysis of phenolic compounds in Ugandan sweet potato varieties (NSP, SPK \& TZ). African Journal of Biochemistry Research, 1, 029-034.

Rooney, L. W., \& Serna-Saldivar, S. O. (1990). Sorghum. In: K. L. Lorenz, \& K. Kulp, (Eds.), Handbook of Cereal Science and Technology (pp. 233-353). New York: Marcel Dekker.

Shahidi, F., \& Naczk, M. (2004). Phenolics in foods and nutraceuticals. London: CRC Press LLC.

Solomon, M. (2005). Nutritive value of three potential complementary foods based on cereals and legumes. African Journal of Food and Nutritional Sciences, 5, 1-14. 
Talcott, S. T., Passeretti, S., Duncan, C. E., \& Gorbet. (2005). Polyphenolic content and sensory properties of normal and high oleic acid peanuts. Food Chemistry, 90, 379-388.

Waterman, P. G., \& Mole, S. (1994). Analysis of Phenolic Plant Metabolites. London: Blackwell Scientific Publications.

WHO/FAO Report. (1985). Energy and protein requirements. WHO Technical report series No.724.WHO Geneva. 
Table1

Proximate composition of flours and porridges $(\mathrm{g} / 100 \mathrm{~g})$ dry basis

$\begin{array}{llll}\text { Protein } & \text { Fat } & \text { Ash } & \text { Carbohydrates }\end{array}$

$\begin{array}{lllll}\text { Flours } & & & \\ \text { SOGF } & 9.9^{\mathrm{a}}(0.2) & 3.0^{\mathrm{b}}(0.2) & 1.4^{\mathrm{a}}(0.1) & 85.7^{\mathrm{l}}(0.0) \\ \text { FUH } & 34.3^{\mathrm{g}}(0.5) & 38.1^{\mathrm{j}}(0.0) & 2.7^{\mathrm{cd}}(0.0) & 24.8^{\mathrm{b}}(0.1) \\ \text { FH } & 34.6^{\mathrm{g}}(0.7) & 39.1^{\mathrm{k}}(0.0) & 2.9^{\mathrm{d}}(0.0) & 23.3^{\mathrm{a}}(0.0) \\ \text { DUH } & 50.0^{\mathrm{h}}(0.5) & 15.3^{\mathrm{i}}(0.1) & 4.2^{\mathrm{e}}(0.1) & 30.5^{\mathrm{c}}(0.0) \\ \text { DH } & 53.2^{\mathrm{i}}(1.5) & 11.2^{\mathrm{e}}(0.0) & 4.7^{\mathrm{f}}(0.1) & 31.2^{\mathrm{d}}(0.0)\end{array}$

Composite flours

$\begin{array}{lllll}\text { FUMSF } & 17.8^{\mathrm{c}}(0.5) & 14.2^{\mathrm{g}}(0.0) & 1.8^{\mathrm{b}}(0.1) & 66.2^{\mathrm{f}}(0.1) \\ \text { FHMSF } & 17.9^{\mathrm{c}}(0.7) & 14.6^{\mathrm{h}}(0.0) & 1.9^{\mathrm{b}}(0.0) & 65.5^{\mathrm{e}}(0.2) \\ \text { DUMSF } & 22.6^{\mathrm{e}}(0.5) & 6.9^{\mathrm{d}}(0.0) & 2.3^{\mathrm{c}}(0.1) & 68.2^{\mathrm{h}}(0.1) \\ \text { DHMSF } & 23.8^{\mathrm{f}}(1.5) & 5.6^{\mathrm{c}}(0.0) & 2.4^{\mathrm{c}}(0.0) & 68.1^{\mathrm{h}}(0.0)\end{array}$

Composite porridges

$\begin{array}{lllll}\text { SOGP } & 11.7^{\mathrm{b}}(0.1) & 1.4^{\mathrm{a}}(0.1) & 1.5^{\mathrm{a}}(0.2) & 85.4^{\mathrm{k}}(0.0) \\ \text { FUMSP } & 18.8^{\mathrm{d}}(0.3) & 12.5^{\mathrm{f}}(0.2) & 2.0^{\mathrm{b}}(0.1) & 66.8^{\mathrm{g}}(0.1) \\ \text { FHMSP } & 18.8^{\mathrm{d}}(0.3) & 12.7^{\mathrm{f}}(0.1) & 2.10^{\mathrm{b}}(0.0) & 66.4^{\mathrm{ef}}(0.0) \\ \text { DUMSP } & 22.9^{\mathrm{e}}(0.2) & 2.9^{\mathrm{b}}(0.2) & 2.4^{\mathrm{c}}(0.2) & 71.8^{\mathrm{j}}(0.1) \\ \text { DHMSP } & 22.6^{\mathrm{e}}(0.17) & 2.7^{\mathrm{b}}(0.1) & 2.6^{\mathrm{c}}(0.1) & 72.1^{\mathrm{i}}(0.0)\end{array}$

\footnotetext{
abcde $=$ mean values within a column with different letters differ significantly $(\mathrm{p}<0.05)$, Standard deviations are given in parentheses DUH: Partially defatted flour from unheated marama beans, DH: Partially defatted flour from heated marama beans, FH: Full fat flour from heated marama beans and FUH: Full fat flour from unheated marama beans and SOGF: Sorghum meal, FHMSF: Full fat flour from heated marama beans - sorghum meal composite, DHMSF: Partially defatted flour from heated marama beans - sorghum meal composite, FUMSF: Full fat flour from unheated marama beans - sorghum meal composite, DUMSF: Partially defatted flour from unheated marama beans - sorghum meal composite, FHMSP: Porridge from full fat flour from heated marama beans - sorghum meal composite, DHMSP: Porridge from partially defatted flour from heated marama beans - sorghum meal composite, FUMSP: Porridge from full fat flour from unheated marama beans - sorghum meal composite, DUMSP: Porridge from partially defatted flour from unheated marama beans - sorghum meal composite and SOGP: Sorghum porridge
} 
Table 2

Energy value of sorghum porridge and marama-sorghum composite porridges $(\mathrm{kJ} / 100 \mathrm{~g})$ dry basis

Type of porridge Gross Energy

Percent increase in energy value $(\%)$ (compared with SOGP)

SOGP

$1724.1^{\mathrm{a}}(0.1)$

NA

FUMSP

$2130.2^{\mathrm{d}}(0.7)$

23

FHMSP

$2134.0^{\mathrm{d}}(0.1)$

24

DUMSP

$1959.4^{\mathrm{c}}(0.2)$

14

DHMSP

$1918.8^{\mathrm{b}}(0.4)$

11

${ }^{\text {abcd }}=$ mean values within a column with different letters differ significantly $(\mathrm{p}<0.05)$, Standard deviations are given in parentheses FHMSP: Porridge from full fat flour from heated marama beans - sorghum meal composite, DHMSP: Porridge from partially defatted flour from heated marama beans - sorghum meal composite, FUMSP: Porridge from full fat flour from unheated marama beans - sorghum meal composite, DUMSP: Porridge from partially defatted flour from unheated marama beans - sorghum meal composite and SOGP: Sorghum porridge, NA: Not applicable 
Table 3

Amino acid composition of marama flours and sorghum meal g/100 g flour (dry matter basis)

\begin{tabular}{|c|c|c|c|}
\hline Amino acid & SOGF & DUH & $\mathrm{DH}$ \\
\hline \multicolumn{4}{|c|}{ Essential amino acids } \\
\hline Histidine & $0.2^{\mathrm{a}}$ & $1.3^{\mathrm{b}}$ & $1.4^{\mathrm{b}}$ \\
\hline Isoleucine & $0.4^{\mathrm{a}}$ & $2.2^{\mathrm{b}}$ & $2.9^{\mathrm{b}}$ \\
\hline Leucine & $1.2^{\mathrm{a}}$ & $3.0^{\mathrm{b}}$ & $3.3^{\mathrm{b}}$ \\
\hline Lysine & $0.2^{\mathrm{a}}$ & $2.8^{\mathrm{c}}$ & $2.7^{\mathrm{b}}$ \\
\hline Methionine & $0.2^{\mathrm{a}}$ & $0.4^{\mathrm{b}}$ & $0.4^{\mathrm{b}}$ \\
\hline Phenylalanine & $0.5^{\mathrm{a}}$ & $2.1^{\mathrm{b}}$ & $2.3^{\mathrm{b}}$ \\
\hline Threonine & $0.3^{\mathrm{a}}$ & $1.5^{\mathrm{b}}$ & $1.6^{\mathrm{b}}$ \\
\hline Valine & $0.4^{\mathrm{a}}$ & $2.2^{\mathrm{b}}$ & $2.4^{\mathrm{c}}$ \\
\hline \multicolumn{4}{|c|}{ Non-essential amino acids } \\
\hline Alanine & $0.8^{\mathrm{a}}$ & $1.6^{\mathrm{b}}$ & $1.7^{\mathrm{b}}$ \\
\hline Arginine & $0.4^{\mathrm{a}}$ & $3.3^{\mathrm{b}}$ & $3.5^{\mathrm{c}}$ \\
\hline Aspartic acid & $0.5^{\mathrm{a}}$ & $4.0^{\mathrm{b}}$ & $4.4^{\mathrm{c}}$ \\
\hline Cysteine & $0.1^{\mathrm{a}}$ & $0.1^{\mathrm{a}}$ & $0.1^{\mathrm{a}}$ \\
\hline Glutamic acid & $1.8^{\mathrm{a}}$ & $7.7^{\mathrm{b}}$ & $8.3^{\mathrm{c}}$ \\
\hline Glycine & $0.3^{\mathrm{a}}$ & $3.0^{\mathrm{b}}$ & $3.2^{\mathrm{c}}$ \\
\hline Proline & $0.8^{\mathrm{a}}$ & $3.6^{\mathrm{b}}$ & $4.0^{\mathrm{c}}$ \\
\hline Serine & $0.4^{\mathrm{a}}$ & $2.6^{\mathrm{b}}$ & $2.9^{c}$ \\
\hline Tyrosine & $0.4^{\mathrm{a}}$ & $6.0^{\mathrm{b}}$ & $6.6^{\mathrm{c}}$ \\
\hline Total amino acids & 8.9 & 47.4 & 51.7 \\
\hline
\end{tabular}


Table 4

Amino acid composition of sorghum porridge and marama-sorghum composite porridges $(\mathrm{g} / 100 \mathrm{~g}$ porridge dry basis)

\begin{tabular}{llllll} 
Amino acid & SOGP & FUMSP & FHMSP & DUMSP & DHMS \\
\hline Essential amino acids & & & & & \\
Histidine & $0.3^{\mathrm{a}}$ & $0.4^{\mathrm{b}}$ & $0.4^{\mathrm{b}}$ & $0.5^{\mathrm{c}}$ & $0.5^{\mathrm{c}}$ \\
Isoleucine & $0.4^{\mathrm{a}}$ & $0.8^{\mathrm{b}}$ & $0.8^{\mathrm{b}}$ & $1.0^{\mathrm{c}}$ & $1.0^{\mathrm{c}}$ \\
Leucine & $1.4^{\mathrm{a}}$ & $1.6^{\mathrm{a}}$ & $1.5^{\mathrm{a}}$ & $1.8^{\mathrm{b}}$ & $1.8^{\mathrm{b}}$ \\
Lysine & $0.2^{\mathrm{a}}$ & $0.7^{\mathrm{b}}$ & $0.7^{\mathrm{b}}$ & $0.9^{\mathrm{c}}$ & $0.9^{\mathrm{c}}$ \\
Methionine & $0.2^{\mathrm{a}}$ & $0.2^{\mathrm{a}}$ & $0.2^{\mathrm{a}}$ & $0.2^{\mathrm{a}}$ & $0.2^{\mathrm{a}}$ \\
Phenylalanine & $0.5^{\mathrm{a}}$ & $0.8^{\mathrm{b}}$ & $0.8^{\mathrm{b}}$ & $1.0^{\mathrm{c}}$ & $1.0^{\mathrm{c}}$ \\
Threonine & $0.4^{\mathrm{a}}$ & $0.5^{\mathrm{ab}}$ & $0.7^{\mathrm{b}}$ & $0.7^{\mathrm{b}}$ & $0.7^{\mathrm{b}}$ \\
Valine & $0.5^{\mathrm{a}}$ & $0.9^{\mathrm{b}}$ & $0.8^{\mathrm{b}}$ & $1.0^{\mathrm{c}}$ & $1.0^{\mathrm{c}}$
\end{tabular}

Non-essential amino acids

\begin{tabular}{|c|c|c|c|c|c|}
\hline Alanine & $1.0^{\mathrm{a}}$ & $1.0^{\mathrm{a}}$ & $1.0^{\mathrm{a}}$ & $1.2^{\mathrm{b}}$ & $1.1^{\mathrm{ab}}$ \\
\hline Arginine & $0.5^{\mathrm{a}}$ & $1.0^{\mathrm{b}}$ & $1.0^{\mathrm{b}}$ & $1.3^{\mathrm{c}}$ & $1.3^{\mathrm{c}}$ \\
\hline Aspartic acid & $0.5^{\mathrm{a}}$ & $1.3^{\mathrm{b}}$ & $1.2^{\mathrm{b}}$ & $1.6^{\mathrm{c}}$ & $1.7^{\mathrm{c}}$ \\
\hline Cysteine & $0.1^{\mathrm{a}}$ & $0.1^{\mathrm{a}}$ & $0.1^{\mathrm{a}}$ & $0.1^{\mathrm{a}}$ & $0.1^{\mathrm{a}}$ \\
\hline Glutamic acid & $1.2^{\mathrm{a}}$ & $3.2^{\mathrm{b}}$ & $3.3^{\mathrm{b}}$ & $4.1^{\mathrm{c}}$ & $4.0^{\mathrm{c}}$ \\
\hline Glycine & $0.4^{\mathrm{a}}$ & $0.9^{b}$ & $0.9^{\mathrm{b}}$ & $1.2^{\mathrm{c}}$ & $1.2^{\mathrm{c}}$ \\
\hline Proline & $1.0^{\mathrm{a}}$ & $1.4^{\mathrm{b}}$ & $1.4^{\mathrm{b}}$ & $1.8^{\mathrm{c}}$ & $1.8^{\mathrm{c}}$ \\
\hline Serine & $0.5^{\mathrm{a}}$ & $0.9^{\mathrm{b}}$ & $0.9^{\mathrm{b}}$ & $1.2^{\mathrm{b}}$ & $1.1^{\mathrm{b}}$ \\
\hline Tyrosine & $0.4^{\mathrm{a}}$ & $1.6^{\mathrm{b}}$ & $1.6^{\mathrm{b}}$ & $2.3^{\mathrm{c}}$ & $2.3^{\mathrm{c}}$ \\
\hline
\end{tabular}

${ }^{a b c d}=$ mean values within a row with different letters differ significantly $(\mathrm{p}<0.05)$, SOGP $=$ Sorghum porridge, FUMSP $=$ Porridge from full fat flour from unheated marama beans - sorghum meal composite, DUMSP = Porridge from partially defatted flour from unheated marama beans - sorghum meal composite, FHMSP = Porridge from full fat flour from heated marama beans sorghum meal composite, DHMSP = Porridge from partially defatted flour from heated marama beans - sorghum meal composite 
Table 5

Fatty acid composition of sorghum porridge and marama-sorghum composite porridges ( $\mathrm{mol} \%$ fatty acid as is basis)

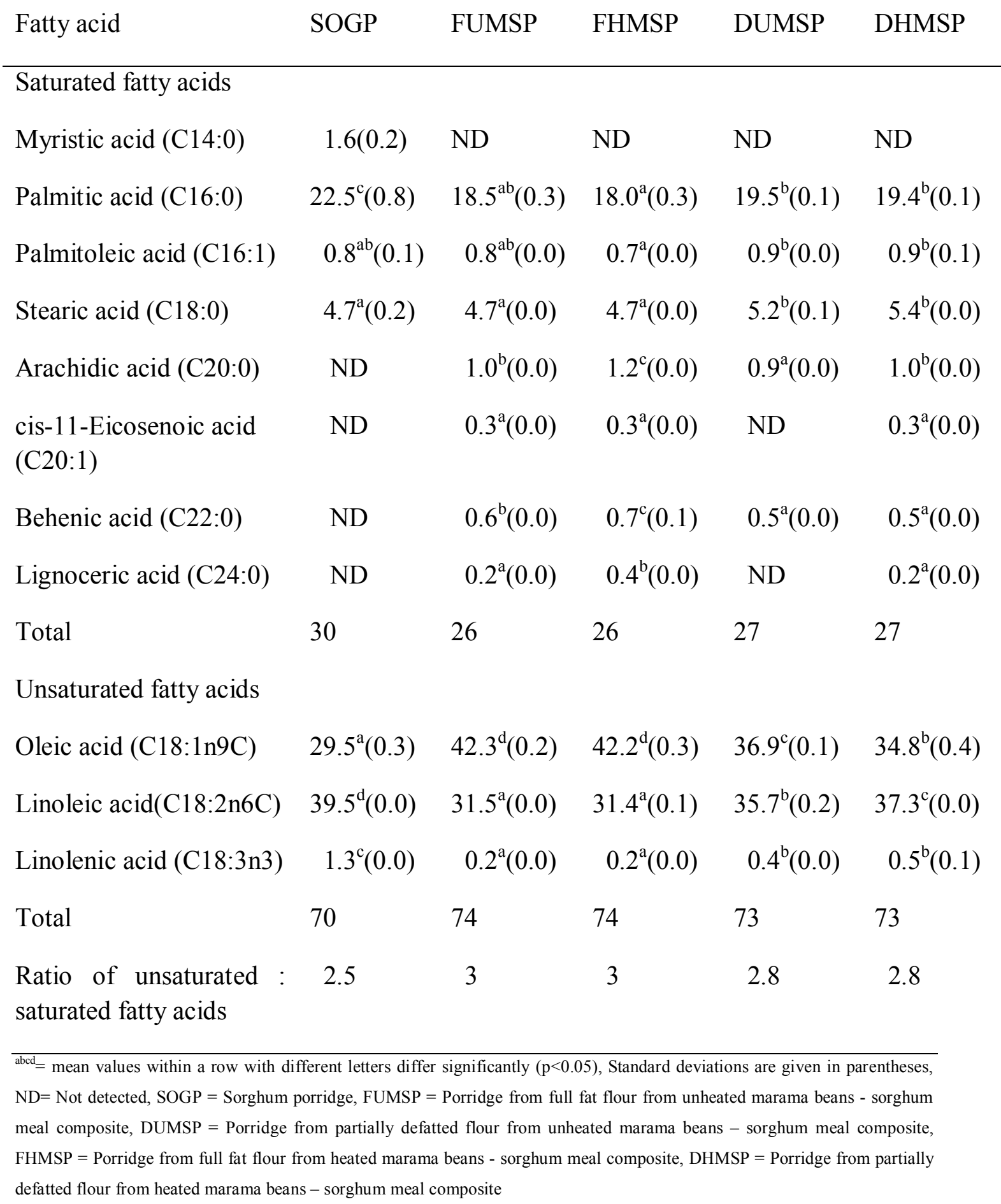


Table 6

Total phenolic content and antioxidant activity of flours and porridges (dry basis)

Total phenolic content ${ }^{\star}$
(mg CE/100mg)

Antioxidant activity ${ }^{\star} \star$ $(\mu \mathrm{MTE} / 100 \mathrm{mg})$

\begin{tabular}{lcc}
\hline Flours & \\
SOGF & $0.7^{\mathrm{a}}(0.1)$ & $3.0^{\mathrm{a}}(0.7)$ \\
FUH & $3.0^{\mathrm{d}}(0.2)$ & $14.1^{\mathrm{d}}(1.1)$ \\
FH & $3.8^{\mathrm{e}}(0.4)$ & $14.3^{\mathrm{de}}(1.3)$ \\
DUH & $4.8^{\mathrm{f}}(0.5)$ & $14.5^{\mathrm{e}}(1.5)$ \\
DH & $5.7^{\mathrm{g}}(0.6)$ & $15.8^{\mathrm{e}}(1.3)$
\end{tabular}

Composite flours

$1.8^{\mathrm{bc}}(0.1)$

$9.5^{\mathrm{b}}(0.9)$

FHMSF

$1.8^{\mathrm{bc}}(0.1)$

$10.8^{\mathrm{b}}(1.3)$

DUMSF

$2.0^{\mathrm{c}}(0.1)$

$12.4^{\mathrm{c}}(1.5)$

DHMSF

$2.1^{\mathrm{c}}(0.1)$

$13.1^{\text {cd }}(1.4)$

Porridges

SOGP

$0.5^{\mathrm{a}}(0.2)$

$2.3^{\mathrm{a}}(0.4)$

FUMSP

$1.5^{\mathrm{b}}(0.2)$

$10.6^{\mathrm{b}}(1.7)$

FHMSP

$1.6^{\mathrm{b}}(0.2)$

$11.1^{\mathrm{bc}}(1.7)$

DUMSP

$2.1^{\mathrm{c}}(0.2)$

$13.6^{\mathrm{d}}(2.1)$

DHMSP

$2.2^{\mathrm{c}}(0.1)$

$13.7^{\mathrm{d}}(2.2)$

\footnotetext{
abcde $=$ mean values within a column with different letters differ significantly $(\mathrm{p}<0.05)$, Standard deviations are given in parentheses DUH: Partially defatted flour from unheated marama beans, DH: Partially defatted from heated marama beans, FH: Full fat flour from heated marama beans, FUH: Full fat flour from unheated marama beans, SOGF: Sorghum meal, FHMSF: Full fat flour from heated marama beans - sorghum meal composite, DHMSF: Partially defatted flour from heated marama beans sorghum meal composite, FUMSF: Full fat flour from unheated marama beans - sorghum meal composite, DUMSF: Partially defatted flour from unheated marama beans - sorghum meal composite, FHMSP: Porridge from full fat flour from heated marama beans - sorghum meal composite, DHMSP: Porridge from partially defatted flour from heated marama beans - sorghum meal composite, FUMSP: Porridge from full fat flour from unheated marama beans - sorghum meal composite, DUMSP: Porridge from partially defatted flour from unheated marama beans - sorghum meal composite, SOGP: Sorghum porridges.

* expressed as mg catechin equivalent per $100 \mathrm{mg}$ sample; **expressed as micro molar trolox equivalent per $100 \mathrm{mg}$ of the sample
} 